\title{
Interannual variability of the Storfjorden (Svalbard) ice cover and ice production observed by ERS-2 SAR
}

\author{
Jörg Haarpaintner, ${ }^{1}$ Peter M. Haugan, ${ }^{2}$ Jean-Glaude Gascard ${ }^{3}$ \\ ${ }^{1}$ Norwegian Polar Institute, Polarmiljøsenteret, N-9296 Tromsø, Norway \\ ${ }^{2}$ Geophysical Institute, University of Bergen, $\mathcal{N}-5007$ Bergen, Norway \\ ${ }^{3}$ Laboratoire d'Océanologie Dynamique et de Climatologie, C.P. 100, 75252 Paris Cedex 05, France
}

\begin{abstract}
The Storfjorden (Svalbard) ice cover has been observed via European remote-sensing satellite (ERS-2) synthetic aperture radar (SAR) over two winters from 1997 to 1999 that showed a high interannual variability in atmospheric forcing. This has resulted in different scenarios in the formation of the ice cover. We reconstruct the icecover evolution with a simple ice-drift and polynya model consistent in parameterization for both winters and with ERS-2 SAR and ground-truth observations. The observations showed that, during the rather cold winter of 1997/98, a fast-ice cover developed over the whole northern part of Storfjorden that closed the ice advection through two sounds. A polynya of up to $6000 \mathrm{~km}^{2}$ developed persistently under northerly winds. The mild winter of 1998/99 showed a different pattern in the Storfjorden ice cover: the fast-ice extent was reduced to the coastal region, so ice motion was more important than in the previous winter. A larger thin-ice and open-water area over the whole fjord resulted in lower total ice production, but relocated the strong ice production sites to shallower waters. Thus, freezing in a large region of shallow waters in the north of Storfjorden in 1998/99 produced denser waters than freezing in a smaller polynya over the deeper centre of Storfjorden during the colder winter 1997/98.
\end{abstract}

\section{INTRODUGTION}

Storfjorden is the biggest fjord in the Svalbard archipelago, covering an area of $13000 \mathrm{~km}^{2}$ enclosed between Spitsbergen in the west and Barentsøya, Edgeøya and Storfjordbanken in the east (Fig. 1). A sill in the south about $120 \mathrm{~m}$ deep separates the Storfjorden waters $\left(7.5 \times 10^{11} \mathrm{~m}^{3}\right)$ from the Barents Sea and Storfjordrenna in particular. Since the 1980 s, very dense brine-enriched shelf water has been observed in Storfjorden (Midttun, 1985; Quadfasel and others, 1988). In 1992 its outflow was measured and its volume was estimated from current meter moorings to be $1.6 \times 10^{12} \mathrm{~m}^{3}$, corresponding to an average rate of $0.05 \mathrm{~Sv}$ (Schauer, 1995). The downstream modification into the Norwegian Sea has been studied using models (Jungclaus and others, 1995) and measurements (Schauer and Fahrbach, 1999). Remote-sensing studies by high-resolution European remote-sensing satellite (ERS-2) syntheticaperture radar (SAR) during winter 1997/98 showed that persistent latent-heat polynyas (Smith and others, 1990) in which important ice production occurs are the origin of the dense shelf waters in Storfjorden (Haarpaintner, 1999). During winter 1997/98, a persistent flaw polynya extended from the fast-ice border at $78^{\circ} \mathrm{N}$ southwards with a maximum extent of about $6000 \mathrm{~km}^{2}$. The evolution of the polynya, observed by satellite, was successfully reconstructed with a polynya model based on wind data from the weather station of Hopen Island (Haarpaintner and others, in press). The polynya was further divided into a thin-ice and an open-water fraction, based on the polynya model from Pease (1987). Using algorithms for frazil-ice production in the open-water area (Cavalieri and Martin, 1994) and for ice growth in thin-, pack- and fast-ice regions (Maykut, 1986), it was shown that more than half of the total ice volume is formed in a $<10 \%$ open-water fraction. About two-thirds are formed in the polynya fraction $(16 \%)$, which includes the above-mentioned open water and thin new ice (Haarpaintner and others, in press). The remotesensing observations by ERS-2 SAR were continued in winter 1998/99. The two winters (1997-99) differed significantly in atmospheric forcing, with the former being quite severe and the latter relatively mild. This was reflected in Storfjorden's ice cover, its evolution over the freezing season and its effects on the physical marine environment and dense water formation in particular.

In the following, we first describe and compare the satellite observations of the ice cover of the two winters. Then we reconstruct these observations with polynya evolution models consistent for both winters and consistent with SAR and ground-truth observations, and calculate the frazil-ice production for the open water and the ice-growth accumulation in the thin-, pack- and fast-ice area. Finally, we discuss the effects of the variability of the ice cover on the production of brineenriched shelf water, with the help of hydrographic measurements taken in spring and summer following both winters.

\section{ERS-2 SAR OBSERVATION}

The ERS-2 SAR is a high-resolution active microwave sensor emitting at $5.3 \mathrm{GHz}$ (C-band) and receiving the reflected signal from the Earth's surface. It is independent of solar radiation and cloud penetration, so it is a suitable instrument for the polar regions during winter. Nevertheless, the interpretation of single SAR scenes of sea ice is not straightforward. 


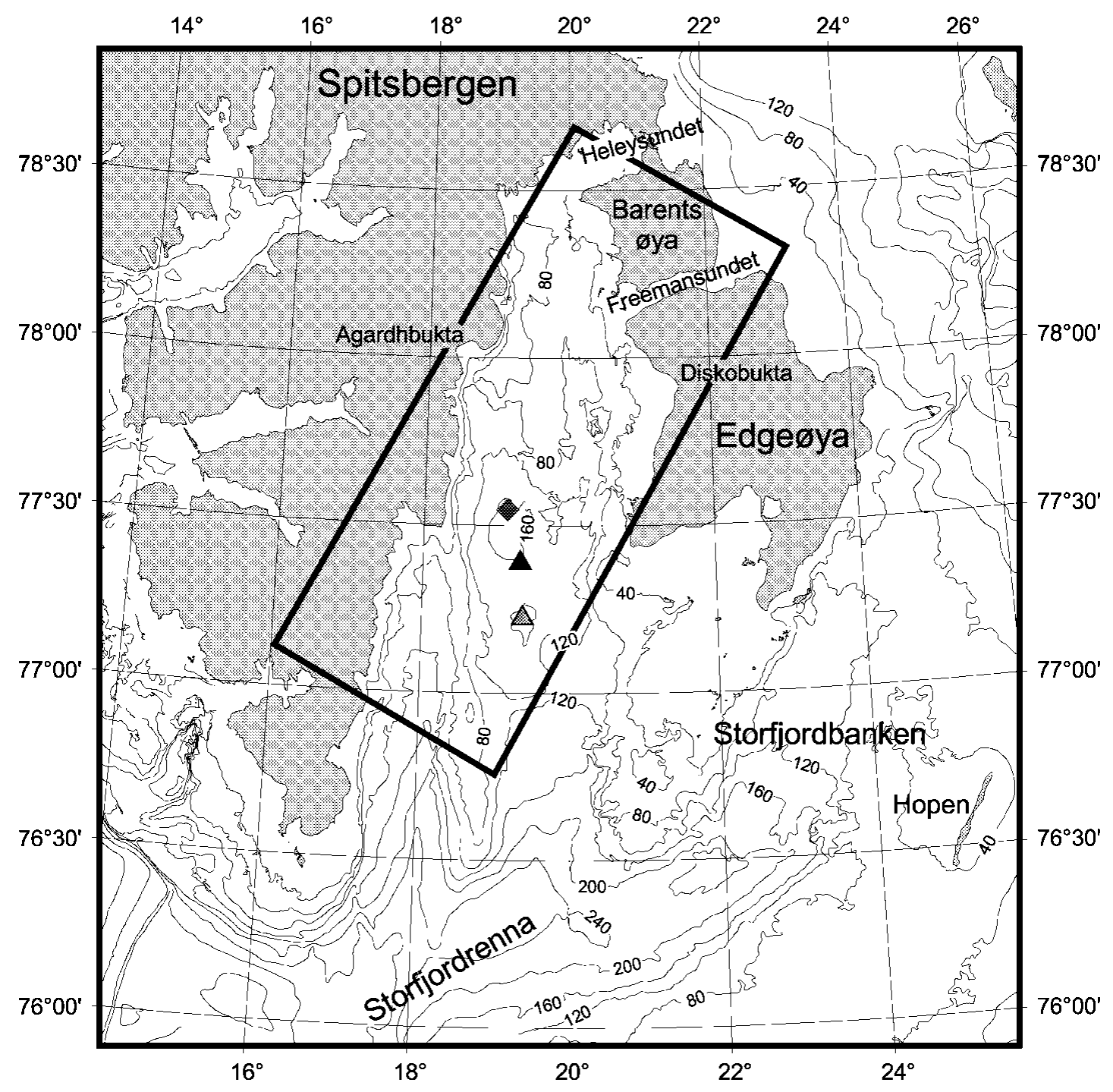

Fig. 1. Storfjorden, situated between Spitsbergen, Barentsøya and Edgeøya. Isobaths at $40 \mathrm{~m}$ depth intervals are indicated as thin lines. The black rectangle is the frame of the SAR scenes, covering about $10000 \mathrm{~km}^{2}$ of Storfjorden. Hydrographic stations are indicated with a grey triangle for April 1998, a black triangle for April 1999 and a black diamond for September 1998, July and September 1999.

Regional knowledge, ground truth and SAR time series, to detect dynamics, are important support for this task (Haarpaintner, 1999). Over the winters 1997-99, 52 SAR scenes of Storfjorden were acquired (Fig. 1), giving the ice conditions on 26 occasions, 13 for each winter. Additionally, ground-truth data and photography were acquired from helicopter and snow-scooter. The meteorological variability between these two winters was very high. Winter 1997/98 was severe, with about 2500 freezing degree-days between 1 November and 31 May. The mild winter 1998/99 had only around 1500 freezing degree-days in the same period (Fig. 2), and slightly stronger wind velocities on average $\left(6.4 \mathrm{~m} \mathrm{~s}^{-1}\right.$ compared to $\left.6.1 \mathrm{~m} \mathrm{~s}^{-1}\right)$, but with a smaller northerly component. This resulted in two different scenarios of the formation and winter evolution of the

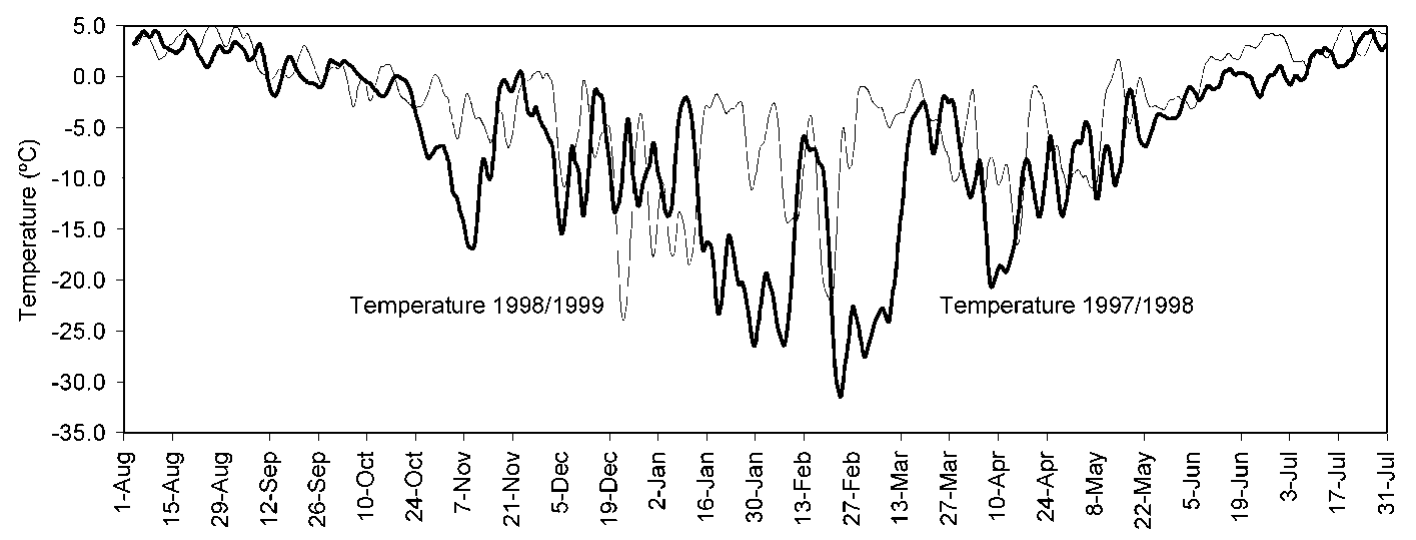

Fig. 2. Air-temperature data at Hopen Island from winter 1997/98 (thick line) and 1998/99 (thin line). 

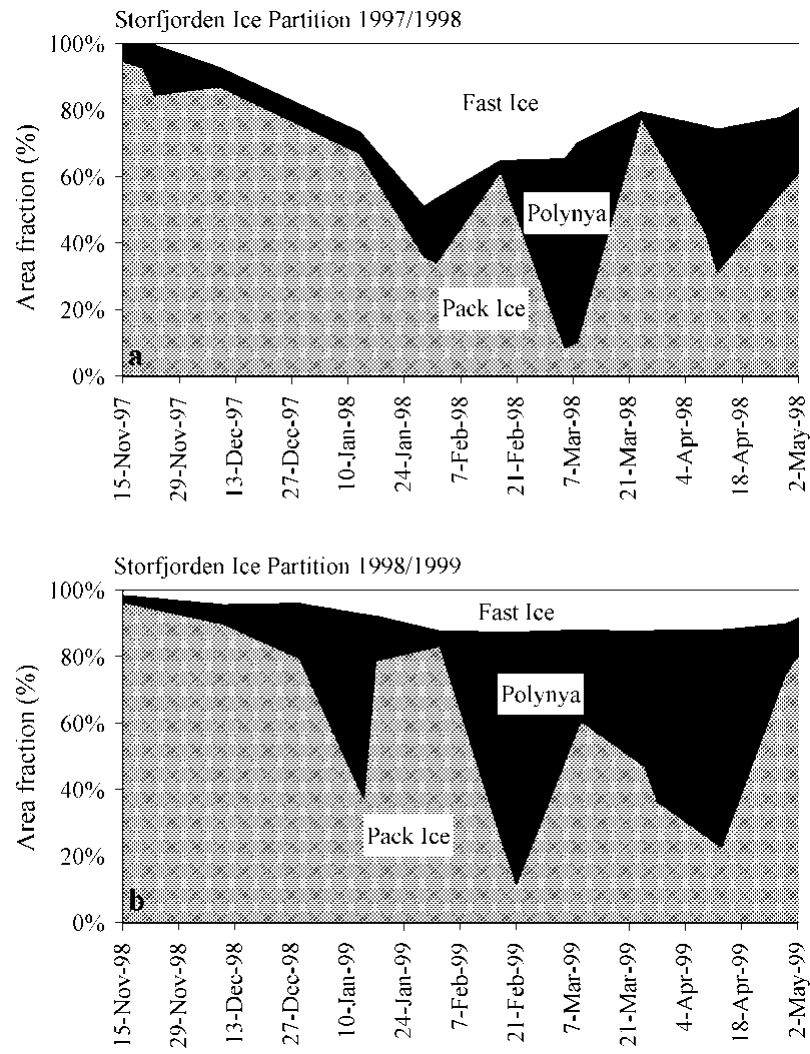

Fig. 3. Partition of the Storfjorden ice cover from ERS-2 SAR images for winters 1997/98 and 1998/99 in the three classes: fast ice, polynya and pack ice. The polynya includes open water and thin ice.

Storfjorden ice cover, and in particular of a persistent latentheat polynya, which we observed by SAR imagery. We emphasize that, in contrast to studies where only open water is considered to be a polynya, in our study the polynya is a highly dynamic area including open water, new thin and brash ice.

In winter 1997/98 (Haarpaintner, 1999), the ice production began in mid-November. At the end of November, most of Storfjorden was covered by a thin-ice cover, i.e. slush and pancake ice, into which the ocean swell, visible on SAR images, could penetrate. The ice cover solidified into a structured ice cover by mid-January. At the end of January, this ice cover broke up northeast of Agardhbukta after 3 weeks with a northerly wind component of about 4-6 $\mathrm{m} \mathrm{s}^{-1}$ on average and maximum wind velocities of $17 \mathrm{~m} \mathrm{~s}^{-1}$, opening a polynya of $2000 \mathrm{~km}^{2}$. At this time, the fast-ice cover reached its largest extent, covering nearly half of inner Storfjorden and especially the whole region north of $78^{\circ} \mathrm{N}$. The polynya closed again by freezing and ice import from southerly winds. From mid- February on, the typical break-off line between Agardh- and Diskobukta is obvious, from which a persistent flaw polynya formed southwards under northerly winds. The break-off line was also observed by ERS-2 SAR in March 1996 (Haarpaintner, 1999). At its largest extent, the polynya covers an area of about $6000 \mathrm{~km}^{2}$ and includes open water and new thin ice, which is involved in strong ridging and rafting.

In winter 1998/99, ice production started at the beginning of December, at least 2 weeks later than in the previous winter, because of milder atmospheric conditions. A relatively homogeneous ice cover is observed over most of Storfjorden in the second half of January, although on 17 January 1999 a coastal polynya from Heleysundet along the west coast of Barents- and Edgeøya developed after 1 week of northeasterly to easterly winds of up to $13 \mathrm{~m} \mathrm{~s}^{-1}$. Since the winter was mild, ice thickness was smaller than in the previous winter, and tidal currents through Heleysundet (Norges Sjokartverk, 1988) may have kept the sea ice under steady motion, preventing it from forming a solid fast-ice cover north of $78^{\circ} \mathrm{N}$, in contrast to $1997 / 98$. Therefore, 2 weeks of north to northeasterly winds of up to $15 \mathrm{~m} \mathrm{~s}^{-1}$ could develop a polynya over the whole of inner Storfjorden by mid-February. Comparable events occurred at the end of March and in mid-April 1999. Hence, the main difference between the two winters lies in the extent of a fast-ice cover over the shallower northern part of Storfjorden, representing an area of about $2000 \mathrm{~km}^{2}$, additionally available in 1998/99 as a potential polynya area. Currents below the ice through the two sounds, Heleysundet and Freemansundet, probably have a profound effect on the location of the polynya.

A manual segmentation of the ERS-2 SAR observations into three classes, fast ice, polynya and pack ice, was made. Figure 3 shows the resultant approximate evolution of the Storfjorden partition into these classes during both winters. As explained in Haarpaintner (1999), this segmentation is based on the texture of the ice and its dynamics in time series. Fast and pack ice may have a similar texture but different dynamics. The polynya is very dynamic and has no specific texture. Its border with fast ice is often very clear, whereas the border with pack ice is often diffuse. This is mainly because the polynya is composed of open water and thin ice, which is often involved in rafting and ridging. On the lee side of the polynya there is often no clear limit between such thin ice and thicker ice floes (pack ice). Figure 4 presents such typical ice conditions from 12 April 1998 and 13 April 1999 together with the manually classified images.

ERS-2 SAR data only give snapshots of ice conditions, but the evolution between observations is important for the heat budget in the ocean-atmosphere systems, and one has to find a reasonable way to interpolate from few observations in time.

\section{MODELLING THE POLYNYA EVOLUTION AND ICE FORMATION}

We apply the same method as in Haarpaintner and others (in press) to interpolate the SAR observations and estimate the polynya and the open-water fraction in inner Storfjorden $\left(\sim 10000 \mathrm{~km}^{2}\right)$, and to calculate the ice production in the fjord. We interpolate the polynya widths observed by satellite using a simple one-dimensional ice-drift algorithm:

$$
\mathrm{PW}_{n}=\mathrm{PW}_{n-1}+A\left(\varphi_{n}-\varphi_{0}\right) B_{1} U_{n} \cos \left(\varphi_{n}-\varphi_{0}\right) \Delta t,
$$

where $\mathrm{PW}_{n}$ is the polynya width at time $n, A\left(\varphi_{n}-\varphi_{0}\right)$ is a factor for opening (i.e. $\cos \left(\varphi_{n}-\varphi_{0}\right) \geq 0$ ) and closing (i.e. $\cos \left(\varphi_{n}-\varphi_{0}\right)<0$ ) of the polynya, both chosen to fit the estimates from SAR observations, $B_{1}$ is the ice-drift factor, chosen at $2-4 \%$ of the wind velocity (Thorndike and Colony, 1982), $U_{n}$ is the wind velocity measured at the nearest weather station (Hopen Island), $\varphi_{n}$ is the wind direction $\left(0^{\circ}=\mathrm{N}, 90^{\circ}\right.$ $=\mathrm{E}$, etc.) measured at Hopen, $\varphi_{0}$ is the dominant wind direction for the opening of the polynya and $\Delta t$ is the time interval of meteorological measurements $(6 \mathrm{~h})$.

For the estimation of the open-water fraction in the polynya, we use the approach of Pease (1987) of calculating the frazil ice that accumulates at the lee side of the polynya, 

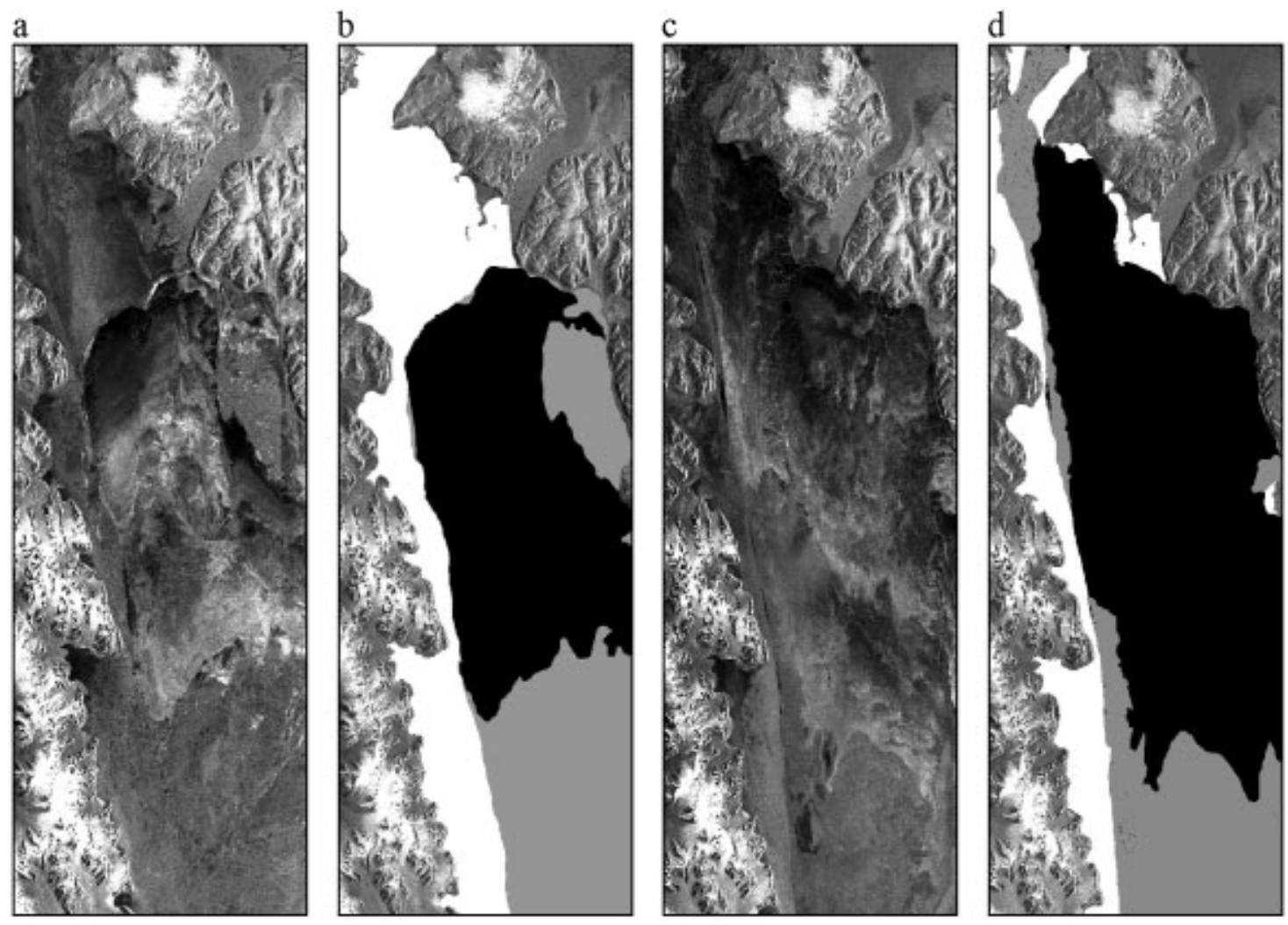

Fig. 4. Typical ERS-2 SAR viewes of the Storfjorden ice covers (a, c) (original data (C) European Space Agency (1998/99), distributed by Eurimage (TSS), and their manual segmentation $(b, d)$ during opening of the polynya in the respective winters on 12 April 1998 ( a, b) and 13 April 1999 (c, d). Fast ice is white, pack ice is grey and the polynya, which includes open water and thin ice, is black.

closing it with a thin ice cover of frazil collection thickness $h_{\mathrm{c}}$, using the algorithm

$$
\mathrm{OW}_{n}=B_{2} U_{n} \cos \left(\varphi_{n}-\varphi_{0}\right) \Delta t+\mathrm{OW}_{n-1}\left(1-\frac{\Delta h_{\mathrm{f}}}{h_{\mathrm{c}}}\right)
$$

where $\mathrm{OW}_{n}$ is the open-water width inside the polynya at time $n, B_{2}$ is the wind factor for frazil-ice drift inside the polynya, $\Delta h_{\mathrm{f}}$ is the thickness of the frazil ice produced between times $n-1$ and $n$, and $h_{\mathrm{c}}$ is the frazil collection thickness to form a thin-ice cover of $20 \mathrm{~cm}$ (Haarpaintner and others, in press). The $20 \mathrm{~cm}$ ice thickness is fixed initially as soon as frazil-ice production has begun in the polynya.

Thus $\Delta h_{\mathrm{f}} / h_{\mathrm{c}}$ is the fraction of the polynya that is covered with new thin ice in the $6 \mathrm{~h}$ time interval of the meteorological data.

For the ice production, we use two different algorithms: frazil-ice formation in the open-water area (Cavalieri and Martin, 1994), and Stefan's law (Maykut, 1986) in the icecovered areas. Thin ice is only present during polynya events and grows during such an event from a starting thickness of $h_{\mathrm{c}}$. Fast and pack ice are both considered as one ice class, thickening over the whole winter.

The algorithm for frazil-ice formation (Cavalieri and Martin, 1994) is:

$$
F_{\mathrm{T}}+F_{\mathrm{L}}-F_{\mathrm{B}}-F_{\mathrm{S}}=F_{\text {net }}=\rho_{\mathrm{i}} L_{\mathrm{s}} \frac{\Delta h_{\mathrm{f}}}{\Delta_{t}},
$$

where $F_{\mathrm{T}}$ is the upward component of turbulent heat flux, $F_{\mathrm{L}}$ is the upward component of the longwave radiation emitted by the sea, $F_{\mathrm{B}}$ is the downward component of the longwave radiation emitted by the atmosphere, $F_{\mathrm{S}}$ is the effective short- wave solar radiation, $\rho_{\mathrm{i}}$ is the density of sea ice $\left(0.92 \times 10^{3}\right.$ $\left.\mathrm{kg} \mathrm{m}^{-3}\right), L_{\mathrm{s}}$ is the latent-heat coefficient for freezing of sea ice at freezing temperature and salinity of $31 \%$ of the initial water salinity, i.e. $L_{\mathrm{s}}=234.14 \mathrm{~kJ} \mathrm{~kg}^{-1}$ (Yen and others, 1991), and $\Delta h_{\mathrm{f}} / \Delta_{t}$ is the produced ice thickness per time unit.

Stefan's law is expressed (Maykut, 1986) as

$$
H^{2}+\left(\frac{2 k_{\mathrm{i}}}{k_{\mathrm{s}}} h_{\mathrm{s}}+\frac{2 k_{\mathrm{i}}}{C_{\mathrm{t}}}\right) H=\frac{2 k_{\mathrm{i}}}{\rho_{\mathrm{i}} L} \theta,
$$

where $H$ is the ice thickness in $\mathrm{cm}, h_{\mathrm{s}}$ is the snow-cover thickness in $\mathrm{cm}, k_{\mathrm{i}}=2.03 \mathrm{~W} \mathrm{~m}^{-1} \mathrm{~K}^{-1}$ is the thermal conductivity of ice, $k_{\mathrm{s}}=0.31 \mathrm{~W} \mathrm{~m}^{-1} \mathrm{~K}^{-1}$ is the thermal conductivity of snow, $C_{\mathrm{t}}=0.24 \mathrm{~W} \mathrm{~m}^{-1} \mathrm{~K}^{-1}$ is the net surface heat exchange, including the sensible, latent and net longwave heat exchange and neglecting the solar shortwave radiation, $\rho_{\mathrm{i}}$ is the ice density, $L$ is the latent-heat coefficient of freezing $\left(\rho_{\mathrm{i}} L=\right.$ $272.14 \mathrm{~kJ} \mathrm{~cm}^{-3}$ ) and $\theta$ is the cumulative number of freezing degree-days calculated from our adjusted Hopen weatherstation temperature data.

The resulting numerical equation is:

$$
\mathrm{d} H=\frac{12.9}{2 H+13.1 h_{\mathrm{s}}+16.8} \mathrm{~d} \theta .
$$

\section{NUMERIGAL RESULTS}

For the numerical calculations, several assumptions have been made, following mainly Haarpaintner and others (in press). The snow cover on the ice reduces the magnitude of the ocean-ice-atmosphere heat flux in Stefan's law. For both years, we assume a daily snow accumulation of $1.2 \mathrm{~mm}$ on fast and pack ice. New thin ice formed from solidified frazil ice is 

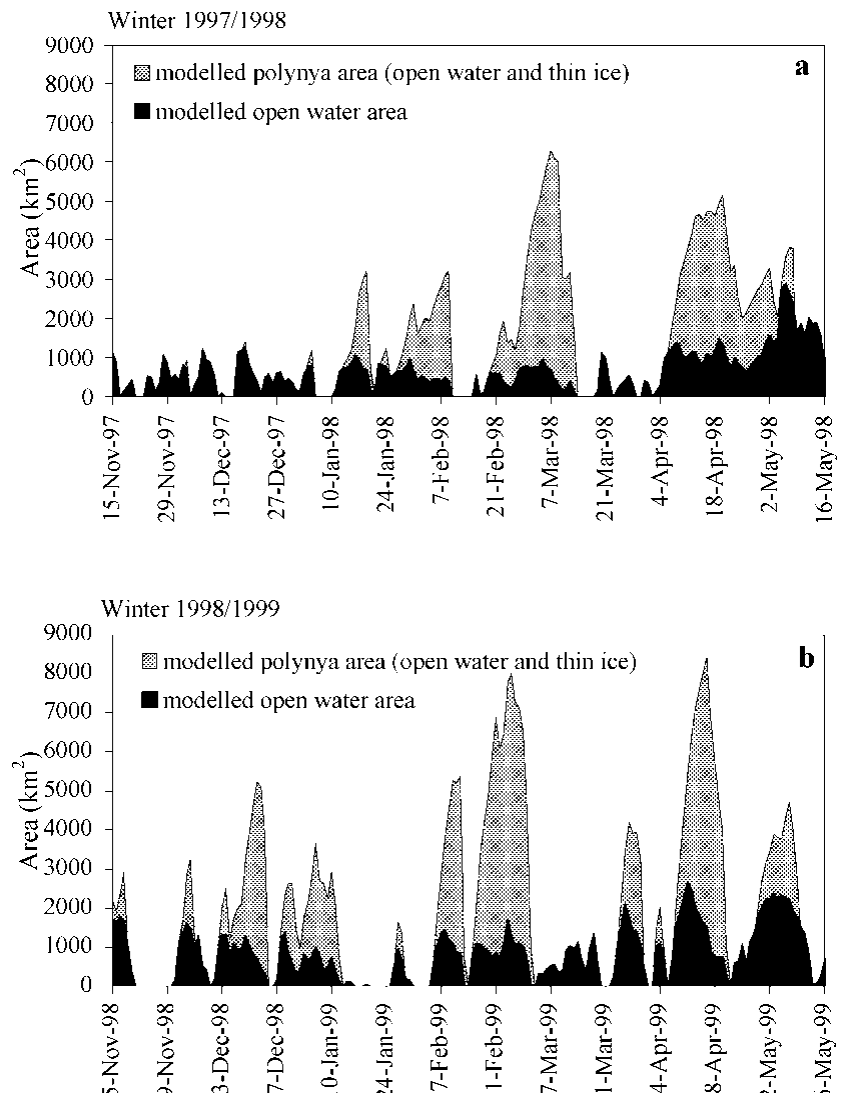

Fig. 5. Modelled size of the polynya and the open-water area for winters 1997/98 ( a) and 1998/99 (b).

considered snow-free in the model. Air temperature in Storfjorden is assumed to be $2{ }^{\circ} \mathrm{C}$ lower than on Hopen Island. Other meteorological data are considered identical to Hopen. The starting date for ice formation has been chosen according to ice maps distributed from the Norwegian Meteorological Institute, as 15 November for 1997 and 1 December for 1998. Assumptions must be made to consider ridging and rafting in thin ice, and lead formation in pack ice; processes which are not included in the model. Strong ridging and rafting were observed during fieldwork by helicopter in spring 1998 and 1999. We assumed that $25 \%$ of thin ice and $1 \%$ of pack ice is opened by these processes. The dominant wind direction $\varphi_{0}$ for the ice drift out of Storfjorden was chosen to be $10^{\circ} \mathrm{W}$, consistent with ice drift $25^{\circ}$ to the right of the wind to follow the main axis of Storfjorden. The ice-drift factors, i.e. open and closing factor for the total polynya (thin ice and open water), were chosen to fit the satellite observation. For 1997/98 we considered a pack-ice drift out of Storfjorden, i.e. opening of the polynya, of $2 \%$ of the wind speed and a closing 15 times faster, an empirical parameterization to take into account the ice production inside the polynya. For 1998/99, opening with $3.6 \%$ of wind speed and closing with $26 \%$ best fitted the observation. The large difference between these empirical coefficients will be discussed later. The ice drift for frazil and thin ice to estimate the open-water fraction according to Pease's model has been chosen to be $4 \%$ of the wind velocity for both years, in contrast to $3 \%$ used for the study of winter 1997/98 in Haarpaintner and others (in press). Following these assumptions, the respective area fraction and ice production of the different ice classes (open water, thin ice and fast/pack ice) were calculated between the starting dates and the following 15 May. Figure 5 shows the modelled evolution of the polynya and open-water area in Storfjorden during both winters. The
Table 1. Modelled spatial fraction and ice production on average during both winters 1997-99 for each ice class

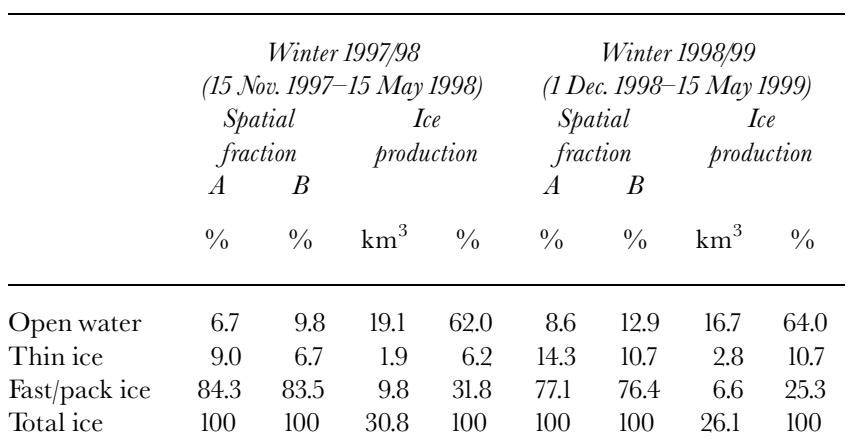

Note: Columns A exclude and columns B include consideration of rafting, ridging in thin ice and lead formation in pack ice.

average area fractions and the ice production for each modelled ice class (open water, thin ice and fast/pack ice) and in total are summarized in Table 1 . The total ice production in the $10000 \mathrm{~km}^{2}$ area is about $15 \%$ lower in the second winter $\left(26.1 \mathrm{~km}^{3}\right)$ than in the first $\left(30.8 \mathrm{~km}^{3}\right)$. Since there were about $40 \%$ fewer freezing degree-days, and only slightly stronger winds, more than half of the lack in atmospheric forcing could be balanced by the difference in the ice cover. The average freezing rate is 1.74 and $1.61 \mathrm{~cm} \mathrm{~d}^{-1}$ for the respective years. A 9.8\% fraction of open water in 1997/98 and a $12.9 \%$ fraction in $1998 / 99$ could both produce $>60 \%$ of the total ice production (19.1 and $16.7 \mathrm{~km}^{3}$, respectively). The thin-ice fraction in 1998/99 was 1.6 times more than in 1997/98 and could therefore produce $47 \%$ more ice $\left(1.9 \mathrm{~km}^{3}\right.$ for 1997 98 , and $2.8 \mathrm{~km}^{3}$ for $\left.1998 / 99\right)$. Thus, the polynya, i.e. thin-ice and open-water areas together, produced a comparable amount of ice in both winters (21.0 and $19.5 \mathrm{~km}^{3}$, respectively), at the expense of the fast-/pack-ice region, which produced about $30 \%$ less fast/pack ice in 1998/99 $\left(6.6 \mathrm{~km}^{3}\right)$ than in $1997 / 98\left(9.8 \mathrm{~km}^{3}\right)$. Brine rejection is assumed to be proportional to the ice production.

Errors are discussed in the sensitivity study of Haarpaintner and others (in press). The total error in the calculation due to inaccuracy of meteorological data is estimated to be $<10 \%$. The main errors are due to problems in distinguishing between the different ice classes, i.e. the empirical values for the ice-drift wind factor, accumulation thickness of frazil ice and empirical estimations of rafting, ridging and lead formation.

\section{DISGUSSION}

In the following we discuss absolute accuracy and relative precision of the results for the two winters. During the coupled remote-sensing/model study we encountered different sources of errors. First, as explained above, the interpretation of SAR images is sometimes ambiguous. Some of the ambiguities can be solved by ground-truth observations at single points in space, by dynamics visible in time series and also to a certain extent by modelling. On some images the limit between thin ice of the polynya and pack ice is so diffuse that the error in the estimate of the polynya width could be several tens of kilometres, as in mid-February 1999. Therefore we have to rely on some more easily interpretable images to find the empirical ice-drift coefficients to model the polynya width with Equation (1). Fast ice, 
Salinity (psu)

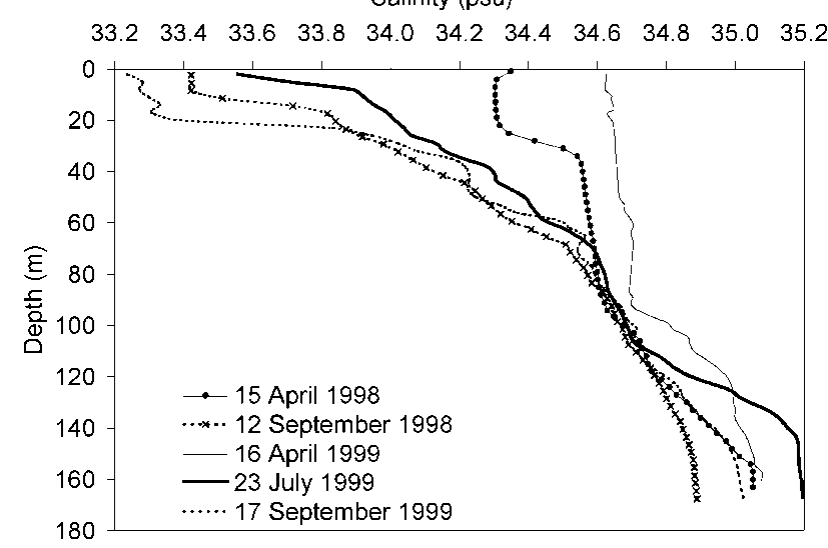

Fig. 6. Salinity profiles in the Storfjorden pool around $77^{\circ} 30^{\prime} \mathcal{N}$ and $19^{\circ}$ E at indicated dates.

easier to distinguish, gives us an upper limit for the possible polynya fraction. Distinguishing open water from thin ice inside the polynya only by visible inspection of SAR imagery is often impossible, and we rely on Pease's approach (Equation (2)) to differentiate between these two. However, under windy conditions, visible Langmuir streaks of frazil ice gave some indication of open water to set the frazil collection thickness to $20 \mathrm{~cm}$. The sensitivity of the model to the different parameters has already been discussed (Haarpaintner and others, in press), but the comparison between two different winters gives us more insight, especially regarding the ice-drift factors for the opening and closing of the polynya. Fitting the model to the satellite observations resulted in an opening rate of $3.6 \%$ of the wind velocity in $1998 / 99$ compared to $2 \%$ in $1997 / 98$. Ice covers in milder winters are thinner, and presumably also less rigid and more sensitive to dynamics, which could explain this difference. Additionally the absence of the fast-ice cover in the north may have enhanced the ice motion in the whole fjord. The ice drift in the Pease model has been set to $4 \%$ of the wind speed. Since we consider here mainly ice drift inside the polynya, i.e. an area of lower ice concentration and mostly thin ice, we admit a faster ice velocity than for pack ice at the lee side of the polynya. An absolute error of $3 \%$ in total ice production might result from this assumption.

Although the model is highly empirical, the results of the two winters are comparable and consistent with the satellite and ground-truth observation, which means a colder winter produced more ice, but the difference in ice production due to milder atmospheric forcing was attenuated to some extent by a larger polynya area. Nevertheless, the strong difference in ice-drift coefficients tends to overestimate the ice production in 1998/99 compared to 1997/98.

During sea-ice formation, more than two-thirds of the salt from the frozen sea water is rejected and added as brine to the water column underneath. Since the amount of rejected salt is proportional to the volume of formed ice, one would expect denser waters with stronger ice formation. However, salinity profiles taken in April and September in the centre of the fjord (Fig. 6) after the respective winters indicate higher salinities over the whole depth in spring, and $>0.1 \%$ higher bottom salinities in summer following the milder winter. The hydrography in Storfjorden is discussed in more detail in Haarpaintner and others (2001). Maus (2000) argues with preconditioning of the source water in the Barents Sea before freezing. Yet, if the $<0.3 \%$ variability between the September surface salinities of 1998 and 1999 is representative for an interannual variation, it might be too low to influence significantly the bottom-water salinity. Based on our satellite observations, we locate one reason in Storfjorden itself and especially in the position of the ice production. Storfjorden includes a large area with variable bottom bathymetry, roughly divisible into a $<100 \mathrm{~m}$ shallow part north of $78^{\circ} \mathrm{N}$ (mostly shallower than $60 \mathrm{~m}$ ) and an up to $190 \mathrm{~m}$ deep pool between $77^{\circ}$ and $78^{\circ} \mathrm{N}$. In winter 1997/98, the northern part was covered by thick fast ice over the whole winter, so little ice could be produced there, and only at a slow rate. The main ice production occurred in the polynya over the deeper part of Storfjorden south of $78^{\circ}$ N. In 1998/99, in contrast, the fast-ice cover was absent and the polynya extended from Heleysundet on over the shallow part and even, at its greatest extent, over the whole fjord. Thus, the thin-ice and open-water fraction together was $43 \%$ larger in 1998/99 than in 1997/98. Therefore, in 1998/99, strong ice production over a large area made the whole fjord saltier during winter, and freezing over the shallow area produced higher bottom salinities than in 1997/98. The salinity anomaly during constant negative buoyancy forcing from brine release is inversely proportional to the average depth of the forcing region. Chapman (1999) showed in a convection model that the density anomaly increases linearly with time to a maximum, which is dependent on the offshore transport by baroclinic eddies developing at the density front. The offshore transport depends on the bottom topography; a sloping bottom, for example, increases the water exchange significantly and thus decreases the density anomaly. A slope of only 0.003 leads to half the maximum density anomaly produced without slope. Storfjorden has steeper slopes south of than north of $78^{\circ} \mathrm{N}$, which would also have decreased the maximum anomaly. Additionally, Storfjorden has a submarine canyon on each side of the fjord descending from the shallow north to the deeper pool. Modelling offshore transport through such canyons reveals high variability (Chapman and Gawarkiewicz, 1995). Chapman and Gawarkiewicz (1997) show the influence of the forcing decay region around the forcing region, which corresponds to the thin-ice region south of the open-water area and the region over which the polynya changes in time. The larger the decay region is, the smaller is the density gradient to the surroundings, and the smaller is the velocity of the baroclinic eddies at the front, which would increase the density anomaly. The thin-ice fraction in Storfjorden was more important in 1998/99, and may therefore have played a role in producing denser waters.

\section{GONGLUSION}

A comparison of the satellite observations of the Storfjorden ice cover over two successive winters revealed high variability in the ice cover and the fast-ice extension in particular. In the milder winter 1998/99, the northern part of the fjord, not covered by fast ice, could operate as a polynya area under suitable wind conditions. This increased the ocean-atmosphere heat flux over the northern part of Storfjorden by one to two orders of magnitude. Hence, the larger polynya area in the milder winter could counteract the lack of atmospheric forcing, and the centre of important ice production was extended to shallower waters. The density anomaly from brine release during ice formation increases 
with decreasing depth and decreasing water exchange by baroclinic eddies that form at the density front. A larger thin-ice area around open water may have contributed to a decrease in the horizontal density gradient, and thus to lower velocities of the baroclinic eddies. A result of the different ice covers during the two winters was therefore a higher maximum salinity of the brine-enriched bottom water after the milder winter. The Storfjorden polynya must be studied over more winters in order to distinguish more clearly between the effects of a larger polynya and the effect of the location of the polynya over shallower waters.

\section{ACKNOWLEDGEMENTS}

This work was funded by grant No. MAS3-CT96-5036 from the European Union and grant No. 127802/720 from the Norwegian Research Council under contract with the Norwegian Polar Institute, Tromsø. ERS-2 SAR data were distributed by the Tromsø Satellite Station for Eurimage (European Space Agency). Meteorological data were distributed by the Norwegian Meteorological Institute (DNMI). Fieldwork was funded by the University Courses on Svalbard (UNIS), the Norwegian Polar Institute (NP) and the Laboratoire d'Océanologie Dynamique et de Climatologie in cooperation. We thank especially S. Maus for his help during the fieldwork in spring 1999. Thanks to the crew of R/V Lance for help with the hydrographic measurements, and to H. Goodwin of the NP for drawing Figure 1.

\section{REFERENGES}

Cavalieri, D. J. and S. Martin. 1994. The contribution of Alaskan, Siberian, and Canadian coastal polynyas to the cold halocline layer of the Arctic Ocean. 7. Geophys. Res., 99 (C9), 18,343-18,362.

Chapman, D. C. 1999. Dense water formation beneath a time-dependent coastal polynya. 7. Phys. Oceanogr., 29(4), 807-820.

Chapman, D. C. and G. Gawarkiewicz. 1995. Offshore transport of dense shelf water in the presence of a submarine-canyon. 7. Geophys. Res., $\mathbf{1 0 0}$ (C7), 13,373-13,387.
Chapman, D. C. and G. Gawarkiewicz. 1997. Shallow convection and buoyancy equilibration in an idealized coastal polynya. f. Phys. Oceanogr., $27(4), 555-566$.

Haarpaintner, J. 1999. The Storfjorden polynya: ERS-2 SAR observations and overview. Polar Res., 18(2), 175-182.

Haarpaintner, J., J. O'Dwyer, J.-C. Gascard, P. M. Haugan, U. Schauer and S. Østerhus. 2001. Seasonal transformation of water masses, circulation and brine formation observed in Storfjorden, Svalbard. Ann. Glaciol., 33 (see paper in this volume).

Haarpaintner, J., J.-C. Gascard and P. M. Haugan. Ice production and brine formation in Storfjorden. F. Geophys. Res. $\mathbf{1 0 6}(\mathrm{C} 7), 14,001-14,013$.

Jungclaus, J. H., J. O. Backhaus and H. Fohrmann. 1995. Outflow of dense water from the Storfjord in Svalbard: a numerical model study. 7. Geophys. Res., 100(C12), 24,719-24,728.

Maus, S. 2000. Reconstruction of deep water formation in Storfjorden on the western Barents Shelf for the period 1955-1999. In European Geophysical Society XXV General Assembly, Millennium Conference of Earth, Planetary and Solar Systems Sciences, 24-29 April 2000, Nice, France. Proceedings. Vol. 2. Nice, European Geophysical Society, CD-ROM.

Maykut, G. A. 1986. The surface heat and mass balance. In Untersteiner, N., ed. Geophysics of sea ice. London, etc., Plenum Press, 395-463. (NATO ASI Series B: Physics 146.)

Midttun, L. 1985. Formation of dense bottom water in the Barents Sea. Deep-Sea Res., 32(10), Part A, 1233-1241.

Norges Sjøkartverk, ed.1988. Den norske los - Arctic pilot. Farvannsbeskrivelse, sailing directions, Svalbard-Jan Mayen. Seventh edition. Stavanger, Norwegian Hydrographic Service; Norwegian Polar Institute.

Pease, C. H. 1987. The size of wind-driven coastal polynyas. F. Geophys. Res., 92(C7), 7049-7059.

Quadfasel, D., B. Rudels and K. Kurz. 1988. Outflow of dense water from Svalbard Fjord into the Fram Strait. Deep-Sea Res., 35(7), Part A, 1143-1150.

Schauer, U. 1995. The release of brine-enriched shelf water from Storfjord into the Norwegian Sea. F. Geophys. Res., 100 (C8), 16,015-16,028.

Schauer, U. and E. Fahrbach. 1999. A dense bottom water plume in the western Barents Sea: downstream modification and interannual variability. DeepSea Res., Ser. I, 46 (12), 2095-2108.

Smith, S. D., R. D. Muench and C. H. Pease. 1990. Polynyas and leads: an overview of physical processes and environment. 7. Geophys. Res., 95(C6), 9461-9479.

Thorndike, A. S. and R. Colony. 1982. Sea ice motion in response to geostrophic winds. 7. Geophys. Res., 87 (C8), 5845-5852.

Yen, Y.-C., K. C. Cheng and S. Fukusako. 1991. Review of intrinsic thermophysical properties of snow, ice, sea ice, and frost. In Zarling, J. P. and S. L. Faussett, eds. Third International Symposium on Cold Regions Heat Transfer, 11-14 June 1991, Fairbanks, Alaska. Proceedings. Fairbanks, AK, University of Alaska, 187-218. 